\title{
The Swedish initiative and the 1972 Stockholm Conference: the decisive role of science diplomacy in the emergence of global environmental governance
}

Eric Paglia ${ }^{1 凶}$

This article applies a science diplomacy lens to examine Sweden's 1967-1968 intervention in the United Nations-the so-called "Swedish initiative"-that led to the seminal 1972 UN Conference on the Human Environment. The three classic science diplomacy typologiesscience in diplomacy, diplomacy for science and science for diplomacy-are employed to structure an analysis of how Swedish diplomats skillfully leveraged science for diplomatic objectives, first for convincing member states of the need to convene a major environmental conference under UN auspices and then to mobilize scientific research internationallyparticularly in developing countries-during the Conference preparatory process. The empirical study, based on archival research and the oral histories of key participants, also brings to light how problems of the human environment were conceived of and shaped by Swedish scientists and diplomats during this embryonic moment of global environmental governance. Through analysis of some of the public pronouncements and key documents drafted during the first phase of the Swedish initiative, the article further considers the role of popular science as a style of science communication that is particularly relevant in the realm of environmental diplomacy. 


\section{Introduction}

he unanimous adoption of Resolution 2398 Problems of the human environment at the twenty-third session of the United Nations General Assembly (UNGA) on December 3rd, 1968 marked the culmination of the first phase of the "Swedish initiative" that set in motion preparations for the United Nations Conference on the Human Environment (UNCHE), eventually held in Stockholm June 5-16, 1972. The diplomatic process leading up to UNGA 2398 had begun almost exactly 1 year earlier with a brief statement before the General Assembly by the deputy head of Sweden's UN mission, an intervention that was followed by several months of interagency consultations led by the Swedish Foreign Ministry and the crafting of a diplomatic offensive to secure international support for the proposed conference. Swedish diplomats, in particular Ambassador Sverker Åström, Sweden's permanent representative to the UN at the time, played an indispensable role in launching and laying the administrative and intellectual foundation of the Conference (Åström, 1992; Engfeldt, 2009), in part by drawing upon and skillfully leveraging the expertize of key members of Sweden's scientific community to demonstrate that the human environment and associated international development issues warranted treatment at the highest level of world politics. This integrated effort of diplomats and scientists helped shepherd the Swedish initiative from the idea stage to what became a major undertaking within the United Nations system, largely led by the Swedish delegation during the first 2 years (Ivanova, 2010).

With the efforts of Swedish diplomats, government officials and scientific experts in New York and Stockholm in focus, this article examines the interaction of science and diplomacy during this formative phase of multilateral environmental diplomacy-a new dimension of international relations that emerged in the late1960s with the initiation of the diplomatic process that led to the first major global conference on issues of environment and development (Engfeldt, 2009, 2019; Grieger, 2012; Schleper, 2019), representing a milestone in environmental history and sustainable development (Sörlin, 2011; Selcer, 2018). The convergence of multilateral diplomacy and scientific expertize at the core of the Stockholm Conference process, which was launched in the midst of a popular environmental awakening in Sweden (Jamison et al., 1990), played a decisive role in advancing the environment as an international issue and initiating the emergence of global environmental governance, manifested in the series of major conferences, agreements and institutions such as the United Nations Environment Program that have taken shape over the past half century (Speth and Haas, 2006; Najam et al., 2006; Ivanova, 2010). The over 4 years of preparations leading up to Stockholm mobilized a broad array of experts and scientific institutions in a global effort to generate a comprehensive body of knowledge on the human environment, with some 20,000 pages of documentation from experts around the world being amassed and distilled into 800 pages of official material for Conference delegates (Stone, 1973). This process and the eventual Conference proved to be a watershed event in the influence of science on international environmental policymaking (Javaudin, 2017).

Drawing upon archival material, historiographical analysis and the oral histories of several key participants directly involved with the Swedish initiative, and theoretical work from the evolving field of science diplomacy (Flink and Rüffin, 2019; Kaltofen and Acuto, 2018), this article explores the nexus of science and diplomacy in advance of UNCHE-an event that catalyzed subsequent international engagement on complex global problems such as climate change and sustainable development, which today represent important focus areas for science diplomacy research (Gluckman et al., 2017; Flink and Rüffin, 2019). The article also aims to provide further insight into some of Sweden's motivations, ambitions and strategies for securing an environmental conference under UN auspices. As the Swedish government currently prepares for the semi-centennial "Stockholm +50 " environmental summit in 2022, examining the first phase of the 1972 Stockholm Conference preparatory process, circa 1967-1970, also affords an opportunity to shed new light on how problems of "the human environment" were conceptualized at this embryonic stage of international environmental politics by some of the central actors responsible for introducing the initiative within the UN system, whose ideas became embedded in the seminal documents and pronouncements of that domain. This study of the Swedish initiative, furthermore, demonstrates how new types of actors-in this case, natural scientists-came to contribute to diplomatic processes in the emergent realm of international environmental politics that took root during the course of 1968 and rapidly developed in the years leading up to the Stockholm Conference.

\section{Science diplomacy and environmental diplomacy as lenses for historical events}

Scholars of science diplomacy see the emergence and expansion of the concept over the past 10-15 years as a reflection of current trends in science policy and foreign affairs; earlier intersections of science and diplomacy were sporadic and could be considered examples of "proto-SD", as opposed to the more "systemic" SD of today (Flink and Rüffin, 2019; Rungius and Flink, 2020). Although the application of a science diplomacy lens to a historical case that took place some 40 years before the concept's articulation might, therefore, seem somewhat anachronistic, this study of the convergence of science and diplomacy surrounding the Stockholm Conference demonstrates that key aspects of science diplomacy, as currently conceived, have historical precedents that date back at least to the late-1960s and the emergence of international environmental politics-a realm of diplomacy that has remained highly reliant on the participation and contributions of science and scientists.

Labeling the diplomatic activities leading up to the Stockholm Conference as environmental diplomacy could likewise be considered to some extent anachronistic. Environmental diplomacy as a concept did not attain widespread scholarly purchase until the 1990s; an early volume applying that perspective, International Environmental Diplomacy (Carroll, 1988) was published in 1988, consisting of contributions by political scientists, legal scholars, diplomats and government officials. Diplomatic practitioners involved with the Swedish initiative, however, did in fact employ the term "environment diplomacy" in the late-1960s to describe their efforts in advance of UNCHE; ${ }^{1}$ and the memoir of Egyptian scientist and diplomat Mostafa Tolba entitled Global Environmental Diplomacy (Tolba, 1998) encompasses a timespan starting in 1973 following his appointment as deputy executive director of the United Nations Environment Program after the establishment of that organization in the wake of the Stockholm Conference.

This article does not aim to separate and distinguish the science diplomacy and environmental diplomacy dimensions of the Swedish initiative. It would be more accurate to characterize the two subcategories of diplomacy-in this case, and likely many if not most instances of international environmental politics in the years since-as deeply intertwined, as science was an intrinsic aspect of Sweden's efforts to convince other UN delegations of the urgency of environmental problems and thereby place the human environment upon the agenda of the United Nations. Yet a contradiction of sorts, explicitly stated in the opening paragraphs of UNGA 2398, can also be seen in the underlying rationale of the 
Conference and the science and environmental diplomacy it encompassed. The Swedish initiative, like much environmentalism of that era, incorporated a strong critique of modern science and technology, identifying them as the root of the contemporary environmental crisis. A key part of the solution proposed by Conference organizers and stated in UNGA 2398 was to cultivate and mobilize even greater scientific knowledge to expose and understand the impacts of modern society on humans and their environment, and foster public awareness and political engagement to combat the crisis.

\section{Science diplomacy dimensions of the Swedish initiative}

Sweden's intervention exhibits characteristics of the three types of science diplomacy laid out in the landmark Royal Society report from 2010: science in diplomacy, diplomacy for science and science for diplomacy (Royal Society, 2010). These three categories provide a useful analytical lens and organizational structure for distinguishing and accentuating the array of applications of scientific knowledge and expertize that supported the Swedish initiative from its outset. The aim of this article is not, however, to simply reinforce and rigidly apply the Royal Society typologies. Through elaborating the innovative and multifaceted deployment of scientific resources in support of Sweden's diplomatic initiative, the purpose is rather to fruitfully employ and further enrich the science diplomacy concept in contributing an empirical account and analysis of a turning point in environmental, as well as diplomatic, history, for which science was an essential component (Warde et al., 2018). The article also offers a qualitative perspective on science diplomacy by emphasizing that the intended audience of a given intervention can strongly condition its scientific content and style of presentation. An example explored below are the series of diplomatic pronouncements during the first phase of the Swedish initiative that can be characterized as performances of popular science, articulated in a style intended to educate and convince non-specialist UN delegates on the scientific merits that motivated a conference on the human environment.

In line with the Royal Society science diplomacy typologies, three dimensions of the Swedish initiative are examined in greater detail. First, how government officials instrumentally applied science in support of the diplomatic initiative. A key aspect, elaborated below at some length, is how the scientific expertize and normative convictions of Swedish biochemist, public intellectual and environmental activist Hans Palmstierna-who was officially tasked with drafting documents outlining the declining state of the global environment and the consequent societal impacts-were adapted by Sverker Åström to provide the scientific substance that underpinned and animated several decisive diplomatic interventions in 1968. The latter included Åström's Palmstierna-inspired statements before the UN Economic and Social Council (ECOSOC), and his pivotal December $3^{\text {rd }}$ speech at the General Assembly. The co-production of diplomatically effective environmental knowledge by Palmstierna and Åströmwho played the respective roles of "diplomat scientist" and "scientist diplomat" (Moomaw, 2018)-represents an early expression of environmental diplomacy, conditioned and supported by a popularized form of scientific expertize that contained strong doses of dramaturgy and moral conviction, as well as a historical contextualization and narrative of humankind's long-term relationship with the natural world.

Second, the article explores Sweden's diplomatic objective of mobilizing science internationally as part of the Conference preparation process. To provide a global overview of environmental problems, and strengthen connections between scientific institutions and government authorities (particularly in developing countries), Swedish diplomats operating through the UN Secretariat called on Conference participants to draft national environmental reports, with Sweden's own national report and a case study on acid rain promoted-among other means by Swedish embassies-as a template for other countries' reports. ${ }^{2}$ Related to that diplomacy for science initiative, the third dimension of this case study in Swedish science diplomacy examines the Foreign Ministry's employment of scientific experts as de facto envoys, dispatched to developing countries in support of scientific, as well as diplomatic, objectives.

\section{Science in diplomacy: the New York-Stockholm science diplomacy nexus}

On March 13, 1968, Göran Bäckstrand-a desk officer at the Foreign Ministry in Stockholm assigned to United Nations matters-received one of several memoranda sent via telex by Sverker Åström, requesting scientific information from government agencies with knowledge on environmental issues. ${ }^{3}$ Åström and his staff at Sweden's UN mission in New York were in the process of developing a diplomatic strategy for convincing member states of the imperative and rationale for convening a major conference on the human environment, yet they lacked expertize on such matters. To obtain the relevant information for the Swedish mission, Bäckstrand reached out to Hans Palmstierna, whom he knew through Sweden's Vietnam War protest movement. ${ }^{4}$ Palmstierna had two weeks earlier taken a position at the Swedish Environmental Protection Agency, established as the first government authority of its kind in the world in July 1967 (McNeill, 2000; Lundgren, 2005). That year also saw the publication of Plundring, svält, förgiftning (Plunder, Famine, Poisoning), Palmstierna's popular science critique on the effects of population growth and modern society's systematic waste of natural resources that he claimed were jeopardizing the global environment and humanity's survival as a species (Palmstierna, 1967). Upon its release in October, Plunder became a national bestseller of Silent Spring stature, thrusting Palmstierna into the spotlight as Sweden's leading environmentalist and a "meta-specialist" that could broadly speak on behalf of the environment for a general audience (Warde et al., 2018; Heidenblad, 2018).

The widespread public perception of environmental crisis precipitated by Palmstierna's polemic constituted a formative moment in Swedish environmental history (Heidenblad, 2018; Paglia, 2015, 2016), and Plunder's powerful societal impact in Sweden emboldened Åström in planning for the Swedish initiative, reassuring him that an environmental intervention in the United Nations would be supported domestically (Åström, 1992). October 1967 also saw two other high-profile scientific interventions aimed at wide audiences warning of mounting environmental risks: an article by soil scientist Svante Odén published in the daily Dagens Nyheter elaborating for the first time the problem of acid rain (Odén, 1967); and the mass market paperback Människans villkor: en bok av vetenskapsmän för politiker (The Predicament of Man-a book by scientists for politicians, Fichtelius, 1967), edited by medical doctor and public intellectual Karl-Erik Fichtelius and featuring essays by twelve prominent Swedish researchers, including physicist Hannes Alfvén and the economist Gunnar Myrdal (Heidenblad, 2018, 2019), both later recipients of the Nobel Prize in their fields. It was during this autumn of surging environmental awareness that three influential Swedes engaged with the United Nations-Inga Thorsson, Alva Myrdal and Sverker Åström-concluded that Sweden should pursue a UN conference on the human environment. To this end, a proposal was put forward at the UNGA on December 13, 1967 by Börje Billner, Deputy Head of the Swedish UN Mission, 
initiating -if only tentatively at that point-a process that would lead to the 1972 Stockholm Conference (Engfeldt, 2009).

The central paragraph of Billner's short statement, which otherwise addresses mostly procedural matters, diagnoses the problem of the human environment as conceptualized at that point by the Swedish UN delegation:

The impact of the technological revolution that is taking place around us is felt by all peoples, irrespective of their present technological level. It has far-reaching effects on the environment of man. The human body and the human mind are subjected to serious and ever-increasing inconveniences and dangers. These are caused by air pollution, water pollution, sulfur fall-out waste, etc. - in short by all the secondary effects related to the process of industrialization and urbanization. ${ }^{5}$

The main themes of technology, urbanization and industrialization as the predominant drivers of a degraded human environment-including transboundary problems such as air and water pollution-are further developed in Åström's aforementioned March 13 memorandum. It also puts forward a detailed diplomatic strategy and outlines what he saw as some of the general objectives of an eventual conference. The latter included what can be characterized as diplomacy for science in so far as one of Åström's stated ambitions was to raise awareness of environmental issues among governments, researchers and the general public, and to bring together in common cause scientists and other stakeholders engaged with safeguarding the human environment-up to and including at the global level. Moreover, in an expression of the science for diplomacy ethos that infused the Swedish initiative with political legitimacy and empirical substance, the memorandum also proposes the creation of a conference preparatory committee comprised of representatives with scientific backgrounds. Their task would be to define in greater detail the topics the Conference should address.

The March 13 memorandum demonstrates Sweden's UN ambassador's substantial diplomatic expertize and in-depth knowledge of the bureaucratic intricacies and political sensitivities within the UN system. It also indicates a degree of reflexivity and scientific understanding on the emerging issue of the human environment-clearly articulated by Åström as not only encompassing the negative effects of modern society on nature, but also the feedbacks of environmental degradation visited back upon humankind. Yet with opposition to the idea of an environmental conference expected from global financial interests, as well as developing countries concerned that such an event might undermine the international development agenda, ${ }^{6}$ Åström realized his diplomatic acumen would have to be convincingly coupled with a more scientifically robust narrative of an increasingly hazardous human environment, including the transboundary effects that required a coordinated effort at the global level. Hence, as Sweden's diplomatic strategy for supporting the initiative continued to evolve during the spring of 1968, fortifying the science in diplomacy dimension became a primary area of focus in anticipation of the upcoming lobbying effort that Åström and his colleagues would mount at the United Nations.

At a meeting at the Foreign Ministry in Stockholm on April 25, 1968 attended by senior officials from an array of government ministries and agencies, Hans Palmstierna, representing the Swedish EPA, was officially tasked with producing a memorandum that could articulate the scientific basis for convening a global environmental conference. The purpose of the conference, as further elaborated at the meeting, was to stimulate international interest in the environment, find ways to regulate transnational environmental problems having no specific country of origin, and to combine efforts in managing environmental problems with the work of international development agencies in order to help developing countries avoid the costly mistakes made by the nations of the global North in the course of their own industrialization. $^{\text {? }}$

The memorandum on the state of the global environment, delivered by Palmstierna in a shorter initial draft in May 1968, ${ }^{8}$ and a more fully developed version in July, ${ }^{9}$ provided Swedish diplomats with science-based evidence and reasoning to help persuade UN member states, some of which had already expressed skepticism towards the initiative, on the importance of convening a global conference to combat the emerging crisis that affected all countries. The documentation delivered by Palmstierna thus enabled Åström and his staff to acquire a degree of "interactional expertize" (Collins, 2004) in constructing their case for a conference. Although solidly grounded in science, the memorandum, as well as additional documentation Palmstierna submitted to Sweden's UN mission in the autumn of 1968, is animated with his profound environmental and social justice convictions, and offers various policy prescriptions for the damage humans were inflicting on the natural world.

The main themes of the Palmstierna memorandum are clearly apparent in Åström's presentations at the ECOSOC spring session on May 24 and the ECOSOC summer session on July 19 in Geneva. ${ }^{10}$ Preceded by a brief but procedurally important Explanatory Memoradum and cover letter addressed to UN Secretary-General U Thant that formally launched the initiative, ${ }^{11}$ both statements before ECOSOC closely track Palmerstierna's primary points (sans the suggested policy responses), as does Åström's scientifically detailed and decisive speech in front of the UN General Assembly in December 1968. What is more, many of the major themes of the memorandum carry through to the unanimously adopted UN General Assembly Resolution 2398 Problems of the human environment, which was largely drafted by the Swedish mission, ${ }^{12}$ and officially put Conference preparations on track (Engfeldt, 2019). Given the successful outcome of the Swedish initiative, signaled by the July 30 adoption of ECOSOC Resolution 1346 (XLV) recommending that UNGA consider proceeding with a human environment conference and followed several months later by the adoption of UNGA Resolution 2398, Palmstierna's memorandum represents a crucial contribution of scientific substance, strongly conditioned by his normative view on the human-environment relationship, that played a significant political role in a seminal moment of global environmental governance. The co-production of effective science diplomacy as contained in Palmstierna's memorandum and Åström's UN statements in 1968 thus warrants examination in greater detail.

Scientist-diplomat and diplomat-scientist: analysis of the Palmstierna-Åström exchange. By way of introducing the memorandum, Palmstierna situates mankind's contemporary predicament within a much longer historical narrative, asserting that humans have always altered their environment to improve their conditions of life. Without such changes, he argues, neither culture nor civilization would have been possible. Palmstierna then presents the previous few decades as a break from this long duration relationship between humans and nature, a time when mankind began consuming natural resources at historically unprecedented rates. Åström expands on this theme in his UN statements, describing the present period as something qualitatively different from earlier historical epochs. What is more, both Palmstierna and Åström argue that the options available to our ancestors, e.g., migrating after exhausting soil fertility in an area, were no longer possible on a fully settled planet. As stated by Åström at the July 19 ECOSOC session: 
During previous historical epochs, when conditions for human life in a certain geographical region were destroyed through human action, civilization could flourish in another region, and movements of population could take place. When the natural environment is destroyed in the world of today, no emigration can solve the problem, neither from one part of the planet to another, nor to another planet. There is no escape from the problems created by the depletion of the resources and by disturbances in the living systems on the thin surface of the earth between soil, water and atmosphere.

Foreshadowing the convergence of environment and development issues that characterized the Conference, and reflecting core values of Swedish foreign policy and Social Democratic ideology, Palmstierna-a committed Social Democrat and party insideralso introduces equity and solidarity issues into human-environment interactions. Although some changes have brought long-term benefits for most inhabitants of the Earth, many have proven to be shortsighted and led to serious environmental harm, according to Palmstierna and echoed by Åström. In some cases, small groups have enriched themselves in the short term while undermining the long run conditions of life for larger populations. What was unique about the historical juncture during which Palmstierna's generation came of age, as described in the memorandum, was the sheer scale of change and the consumption of natural resources made possible by modern science and technology, accessible to an ever-growing global population. Palmstierna implies that industrial development over the previous few decades had even endangered the survival of humankind.

An overarching theme of the Palmstierna memorandum, and almost identically articulated in Åström's UN statements, is the idea that environmental degradation and overconsumption of natural resources had become a structural condition of the industrial world that could and should be avoided by developing countries. According to Palmstierna:

Usually the signs of environmental destruction are most pronounced in countries where industrialization and urbanization have been most highly developed. When more countries enter the path of rapid industrialization, and get still bigger cities, the problems grow global. The gross destruction of the resources of Nature, that is still the dominant feature of the developed countries, should not necessarily be repeated by the developing countries.

In his critique of industrialization to date, Palmstierna identifies "modern science and technology" as the primary drivers of environmental destruction, which had not yet been fully visited upon countries of the global South that were still in less advanced phases of development. Learning from and avoiding the mistakes of the industrialized world, where environmentally unsound ways of life had already become structural, was therefore a primary motive for convening a conference that would include countries at all levels of development. The lessons learned by the Northern industrial nations at great environmental cost, as well as those scientific and technological advances that might help reduce at least some of the negative consequences of industrialization, should, according to Palmstierna and Åström, be shared with states at an earlier stage of development.

The need for convening an environmental conference at the global level was also anchored in the scientific worldview put forward in the memorandum. Transboundary pollutant flows and the finity of natural resources on a planetary scale tied countries together in a common plight, according to Palmstierna's conceptualization of the environmental problems that humanity collectively faced. These were embedded within and manifested through what he described as "the basic components of the physical environment of man": fertile soil, fresh water of high quality and of sufficient quantity, living oceans, and air of the right composition and the right temperature. Humankind's reliance on these four components of the planetary environment, which could not be contained by national borders, provided a scientific rationale for managing transboundary problems at the highest global level and necessitated an unprecedented level of global solidarity. "A prerequisite to the solution of these problems is an intimate and trustful cooperation between all the nations of this globe", as stated by Palmstierna in the memorandum.

In terms of specific environmental impacts and their anthropogenic drivers, Palmstierna revisits three themes that had formed the basis of Plunder, Famine, Poisoning: the overexploitation of natural resources, explosive global population growth, and the chemical contamination of the environment and human bodies, with "environmental poisons" such as DDT in focus (transported through, e.g., fresh water and the ocean currents, embedded in the food chain in the form of fish and other animals that are consumed by humans). Although these were not novel issues in the late-1960s-having already generated considerable international attention-other environmental problems taken up in the memorandum were less well known at the time, particularly among the non-specialist diplomats and political decision-makers that were Palmstierna and Åström's intended audience. Demonstrating the cutting-edge nature of the science that underpinned Sweden's diplomatic intervention, environmental issues that emerged more prominently in the 1970s were foreshadowed by Palmstierna and Åström, including acid rain, eutrophication and climate change. Regarding the latter, for example, Åström stated before ECOSOC on July 19, 1968, "that man has already rendered the temperature equilibrium of the globe more unstable". ${ }^{13}$

The December 1968 speech became the first occasion on which climate change was brought up at the United Nations General Assembly (Linnér and Selin, 2018). Interestingly, and indicative of the state of scientific understanding at that time, both global cooling (due to the reflectivity of particles on solar radiation) and global warming (caused by heat-trapping carbon dioxide emissions) are mentioned as potential climate change scenarios by Palmstierna and Åström in the memorandum and ECOSOC statements, respectively. By the time of Åström's speech before the UNGA, Lars-Göran Engfeldt, a young diplomat at the Swedish UN mission who drafted the text together with Åström, had through his own reading of media reports on climate change during autumn 1968 concluded that scientific opinion was shifting towards warming as the more likely outcome of human interference in atmospheric processes. ${ }^{14}$ Hence, in contrast to Palmstierna's memorandum and Åström's statements at ECOSOC earlier that year-which presented the particle-induced cooling scenario first-the UNGA speech instead foregrounded and explained in far greater detail the potential for a rise in the Earth's surface temperature caused by increasing concentrations of carbon dioxide, which is presented in the speech as a pollutant. $^{15}$

No other forms of air pollution are mentioned in Åström's December 1968 speech, including acid rain, which Palmstierna had in his memorandum gone into some detail in describing in terms of the scientific basis, and its environmental and economic effects. ${ }^{16}$ Although the issue was brought up by Åström in his May 24 statement, it was excluded from his General Assembly speech in December. While preparing the latter, Engfeldt inquired with the Foreign Ministry, which in turn consulted the Swedish EPA, on whether acid rain could, on scientific grounds, be 
included in the speech. He was informed that there was not enough evidence to make such a claim, and therefore left out any mention of acid rain (Engfeldt, 2009). ${ }^{17}$ Several years later-again reflecting the advances in scientific understanding of environmental issues during that period-Sweden's primary national case study for UNCHE was devoted to precisely the problem of acid rain (Bolin et al., 1971), an influential document that was along with Sweden's national environmental report distributed to other countries during the Conference preparatory period.

\section{Diplomacy for science: national environmental reports and the mobilization of expertize}

In the wake of the adoption of UNGA Resolution 2398, some of Sweden's less apparent conference goals began being shaped in New York by Ambassador Sverker Åström and Lars-Göran Engfeldt, the junior diplomat who had joined the Swedish UN delegation in the autumn of 1968. Several weeks after the resolution, Phillipe de Seynes, the UN undersecretary-general for economic and social affairs, discreetly approached Åström to seek Sweden's assistance in supporting the UN Secretariat with scientific knowledge on the environment, which was sorely lacking at the top levels of the United Nations at that time. To this end, Engfeldt became informally attached to the UN Secretariat, serving as a conduit for Swedish expertize. Sweden's UN delegation was in this way able, at an early stage, to influence conference preparations while significantly increasing the capacity of the Secretariat and its Office of Science and Technology, where Engfeldt was placed. ${ }^{18}$

This close association with the Secretariat enabled Åström and Engfeldt to further pursue an underlying objective of stimulating the production and coordination of environmental science in UN member states, particularly in developing countries. Many national governments and civil societies in the global South had extremely limited awareness and understanding of domestic environmental conditions. Weak institutional coordination at the national level for producing and disseminating the knowledge necessary for managing environmental problems was another significant impediment. For the Swedish diplomats, the conference-from early on in the preparation stage-was thus a means for mobilizing government authorities and building institutional capacity at the national level in developing countries. Åström realized, moreover, that decisions taken by UN representatives in New York would have little de facto impact without deeper engagement in their respective domestic contexts. This was particularly true for developing countries, which often had small delegations and weak government institutions. ${ }^{19}$

The production of national environmental reports was, therefore, conceived of as a method for catalyzing the scientific and societal mobilization imagined by Åström and Engfeldt. On behalf of the UN Secretariat, they drafted a circular letter distributed to member states in January 1969, requesting that as part of Conference preparations, each government should produce a national report on the state of their domestic environment. This request, together with additional instructions on drafting national reports and environmental case studies in two follow-up letters, was formulated in such a way that compelled foreign ministries to engage other government agencies to answer specific questions and begin producing a national environmental report. Through the report production process, the Swedish diplomats sought to stimulate widespread governmental commitment and coordination among scientific institutions and, more generally, societal awareness and public concern over environmental issues. Broader domestic participation in preparing for the conference would, Åström and Engfeldt believed, not only lead to a more productive and politically meaningful conference, but would also bring about a more enduring impact on societies that had limited capacity for dealing with the environmental problems they were in the early stages of confronting. ${ }^{20}$ The mobilization succeeded in enhancing the previously low-level of engagement in environmental issues and resulted in the submission of over 80 national reports (Strong, 1972, McCormick, 1989). Preparing national reports, moreover, became a precedent replicated in the run-up to the Rio Earth Summit (Antrim, 1994).

Such a marshaling of expertize was in the works in Sweden with the formation in 1969 of the Committee for Research and Factual Issues (Kommittén for forskning och andra sakfrågor, hereafter CRF). This ad-hoc governmental body, situated directly under the National Committee within Sweden's organizational structure for Conference preparations, played a central role in the coordination and integration of scientific expertize and environmental diplomacy that characterized Swedish activity during the preparatory phase of the Stockholm Conference (Mårtenson, 2000). The Committee was led by Arne Engström, a professor of medical physics and molecular biology at the Karolinska Institute in Stockholm who also served as secretary of the Swedish Research Council. The latter position provided him direct access to the Prime Minister and afforded the CRF a degree of independence in the internal struggle between the Foreign Ministry and the Ministry of Agriculture for overall leadership of Sweden's conference preparations. The relative autonomy enjoyed by the Committee-comprises diverse high-level experts, including Palmstierna and climate scientist Bert Bolin, ${ }^{21}$ representing an array of government, industry and academic institutions-helped ensure that issues of scientific substance would not be compromised by Swedish domestic politics, and help influence the development of a robust, knowledge-based foundation for the conference. $^{22}$

The primary task of the Committee was to oversee the drafting of Sweden's own national report. In addition to the national report, published in Swedish and English versions, ${ }^{23}$ three thematic reports were produced under the auspices of the Committee, including one promoted as Sweden's national case study for the Conference: Air pollution across national boundaries: The impact on the environment of sulfur in air and precipitation (Bolin et al., 1971)-one of the first major scientific publications on the emerging transnational problem of acid rain. ${ }^{24}$ Sweden's national report, along with the thematic reports, also served as a diplomatic instrument intended to advance the Swedish objective of stimulating environmental knowledge production and scientific coordination in developing countries. For this purpose, the Swedish national report was employed as a template for developing countries in their own production of environmental reports for the conference. This process was further abetted by the Foreign Ministry, which instructed its embassies around the world to distribute the Swedish national report and acid rain study, and assist developing countries in drafting of their own national reports (Engfeldt, 2019). ${ }^{25}$

\section{Science for diplomacy: an unorthodox diplomatic offensive}

Another dimension of Sweden's pre-conference science diplomacy was the deployment of scientists as de facto diplomats operating on assignment of the Swedish Foreign Ministry. Their mission was to provide additional support to local experts and officials in certain countries in the preparation of national reports, an initiative that some other developed countries such as Canada also participated in (Rowland, 1973). This "unorthodox diplomatic offensive", as one participant, Lars Ingelstam, describes it, further demonstrates a key component of Sweden's diplomatic strategy throughout the preparation phase: the leveraging of Swedish expertize to motivate and secure UNCHE in the face of 
skepticism towards the conference, and to stimulate broader societal engagement with environmental issues, especially in developing countries, while establishing a geographically broadbased foundation of scientific knowledge on the global environment in advance of Stockholm. ${ }^{26}$

Zambia and Brazil, both of which were members of the UNCHE preparatory committee, were identified by the Foreign Ministry as countries that could benefit from greater Swedish assistance in preparing national reports. Since Sweden had existing ties to Zambia through development assistance programs, Swedish government officials had some insight into the country's scientific capacity, which were deemed insufficient for composing a comprehensive report on the environment. Herrick Baltscheffsky, a molecular biologist at Stockholm University, was in 1970, therefore, dispatched by the foreign ministry to Lusaka, where he spent several weeks leading local experts in helping to write the Zambian national report. Lars Ingelstam was sent to Brazil in a similar yet more diplomatically sensitive scientific mission. A mathematician, planning theorist and systems analyst, Ingelstam was a co-author of the acid rain case study. He had become associated with the CRF, which had commissioned the study, through an earlier association with Arne Engström, and in turn came into contact with the foreign ministry's Göran Bäckstrand, who served as one of the Committee's influential secretaries. As preparations for the Conference entered an increasingly fraught phase, Ingelstam's expertize in systems theory came to represent a useful asset in Sweden's novel science diplomacy initiative.

By 1970, Sweden's Foreign Ministry had become concerned over the emergence of developing country discontent over the premise and intentions of the conference. That summer, the development of MIT computer engineer Jay Forrester's systems dynamics model - which would underpin the 1972 Club of Rome report The Limits to Growth (Meadows et al., 1972; Rowland, 1973; Ingelstam, 2012; Warde et al., 2018)-reinforced the growing suspicions among developing countries that the industrialized North aimed to curtail economic growth in the global South. A perception was taking shape in some developing country capitols that the upcoming UN conference was not only a distraction from the international development agenda, but an initiative intended to prevent them from exploiting their natural resources and deny them the prosperity the North had already secured for itself at the expense of the environment (Bäckstrand, 1972; Engfeldt, 2009; Marklund, 2019). Although such concerns were addressed and to some extent alleviated at a June 1971 gathering of development experts in Founex, Switzerland-a landmark event that concluded that environmental protection and economic development were not intrinsically incompatible (Caldwell, 1990; Ivanova, 2010), the environment-development dichotomy and North-South divide represented an enduring issue for the Conference preparation process and well beyond (Macekura, 2015; Paglia and Sörlin, 2021).

Swedish officials regarded the mounting criticism as a substantial threat that could potentially derail preparations and undermine the conference. Brazil was considered a particular cause for concern due to its outspoken opposition to any initiative that could limit its sovereignty over natural resources and constrain economic growth. In various United Nations fora, Brazil's military government strongly criticized the upcoming conference, calling it a "rich man's show" while leading Latin American countries in instigating opposition, and perhaps even a boycott, within the UN through the G77 (Bäckstrand, 1972; Kennet, 1972; Engfeldt, 1973; Engfeldt, 2009; Macekura, 2015; Marklund, 2019). The case was argued even from within the conference's Preparatory Committee by Brazilian diplomat Miguel Almeida Ozorio (Strong, 2000). Owing to its influence as a major developing country, endowed with a rich ecological heritage, mitigating Brazil's skepticism became a critical task for the conference organizers, including the Swedish diplomats and Foreign Ministry officials at the forefront of the preparatory process.

Under these circumstances, Lars Ingelstam was deployed as an unofficial scientific envoy to Brasilia and Rio de Janeiro, where he spent a week meeting with scientists, parliamentarians and government officials. Although his mission was ostensibly to provide expert advice and guidance in the drafting of the Brazilian national report, his primary diplomatic imperative was to clarify the scientific rationale for the Conference, and-drawing upon his expertize in systems theory-reassure officials that industrialized countries were not intent on limiting the developing world's prospects for economic growth and prosperity. The underlying logic of the conference, as explained by Ingelstam, was rather to foster global cooperation on environmental issues in order to meet the challenges that all countries faced in common. His series of presentations were received with great interest by Brazilian officials and scientists, even if he was often informed that real decision-making power rested with the ruling military regime, which maintained its strongly pro-development stance up through the actual Stockholm Conference and after. ${ }^{27}$

\section{Concluding discussion}

The origins of global environmental governance can, as this article has explained, be traced back to a nexus of diplomats, scientists and government officials in Stockholm and New York through which the Swedish initiative emerged and evolved, and eventually culminated in the 1972 UN Conference on the Human Environment. This late-1960s and early-1970s historical episode demonstrates how environmental diplomacy was, from the outset, closely coupled with science diplomacy. Encompassing not only trained diplomats that were able to adeptly apply scientific expertize for establishing the environment as an issue of international politics, environmental diplomacy also involved the scientists themselves-actors whose participation in the diplomatic domain played a vital role in the success of the Swedish initiative. Fortuitously, Sweden had access at the seminal moment of multilateral environmental diplomacy to a cadre of experts able to formulate a convincing scientific case for an audience composed of diplomats at the United Nations, and to follow upon the first phase of the Swedish initiative with a series of additional science diplomacy engagements.

In particular, the successful outcome of the Swedish initiative in its first year was facilitated by the expertize of a seasoned diplomat-scientist who was able to curate and adapt the writings of a scientist-diplomat who only months before had penned a popular science bestseller that-like the documents he drafted in support of Sweden's diplomatic offensive-combined scientific knowledge with declensionist drama and a historical narrative of how modern society had come to pollute and poison the human environment. The complementary skillsets of Sverker Åström and Hans Palmstierna in this way converged in the co-production of a popularized scientific account of the societal risks driven by widespread environmental degradation that enabled the unanimous passage of UNGA 2398 in December 1968. That resolution, like the diplomats and scientists that implemented the Swedish initiative, expressed significant skepticism towards science and technology, yet called for a major expansion of international scientific cooperation as a means for better understanding and addressing the pernicious effects of modern society on the human environment. This apparent paradox in the relationship between science and technology on the one hand and protection of the environment on the other is perhaps less pronounced in public discourse today, but contrasting perspectives, 
between for instance pro-technology ecomodernism and valuesbased interventions such as Pope Francis' 2015 encyclical on the environment Laudato Si', continue to divide environmentalist thought (Paglia, 2016).

While the science in diplomacy aspect of the Swedish initiative is apparent in Åström's UN statements, the diplomacy for science imperative of UNCHE is also clearly stated in UNGA 2398, which expresses "strong hope that the developing countries will, through appropriate international cooperation, derive particular benefit from the mobilization of knowledge and experience about the problems of the human environment" (UNGA, 1968, emphasis in original). In this sense, the pathway of industrialization taken to date could serve as a cautionary tale for developing countries, with the UN conference being the catalyst and conduit for a broad range of expertize and experience flowing from North to South to promote a more environmentally benign development paradigm. During the Conference preparatory phase in the years following the resolution, knowledge mobilization was realized in substance and process through the novel national report initiative conceived by the Swedish diplomats operating through the UN secretariat. The innovative use of Swedish embassies to circulate Sweden's national report and acid rain case study also contributed - in a subtle but substantial way-to shaping the international perception of problems of the human environment, and how such problems could be engaged with through science. Further, in cases such as those elaborated above, the mobilization of knowledge was supported by Swedish experts deployed to developing countries on missions that served both diplomacy for science and science for diplomacy purposes.

The science diplomacy intrinsic to the Swedish initiative also underpinned what was inherently a major effort in public diplomacy, initially played out within the United Nations, intended to bring environmental issues to the attention of a worldwide audience. As articulated in UNGA 2398, drafted by Sweden's UN delegation, a main motivation for organizing a global conference was "to provide a framework for comprehensive consideration within the United Nations of the problems of the human environment in order to focus the attention of Governments and public opinion on the importance and urgency of this question and also to identify those aspects of it that can only or best be solved through international co-operation and agreement" (UNGA, 1968). Given the organizers' ambition of informing, educating and mobilizing a broad stakeholder basestimulating concrete action at the national, regional and international level was another stated goal of UNGA 2398-much of the science contained in the substantial documentation and communication efforts in advance of UNCHE (Stone, 1973), including material such as the unofficial Conference report Only One Earth compiled and curated by top international experts (Ward and Dubos, 1972), was presented in a popularized form primarily for the consumption of non-scientist delegates and general populations around the world (Stone, 1973; Schleper, 2019).

Contemporary environmental discourse and diplomacyespecially when directed towards broader public audiencescontinues to encompass a significant amount of popular science, often combining data and drama in evoking a state of global crisis, communicated by diplomatic officials, environmental advocates and scientific experts alike (Paglia, 2018). This is particularly relevant in cases where the stakes of environmental diplomacy are understood as greater than the zero-sum games of negotiations for national advantage. For example, when the planet and humanity as a whole are conceptualized as stakeholders in common, as Sweden's former chief climate negotiator Ambassador Bo Kjellén suggested in his aspirational idea of a "new diplomacy for sustainable development” (Kjellén, 2007), efforts to mobilize international opinion and awareness in support of collective action on environmental problems in effect synthesize elements of popular science and public diplomacy. From a planetary stakeholder perspective, activist-popularizers such as $\mathrm{Al}$ Gore and Greta Thunberg, as well as officials like former UNFCCC Executive Secretary Christina Figueres, can be seen as playing de facto public diplomacy roles when communicating, championing and popularizing IPCC science for the purpose of increasing global interest and infusing urgency into UNFCCC negotiations-otherwise conducted by diplomats and trained specialists in complex and highly technical topics such as global temperature targets (Paglia and Isberg, 2021).

Applying a science diplomacy lens in providing an empirical account of the Swedish initiative that led to the 1972 Stockholm Conference, this article has thus provided a qualitative perspective on a style of scientific communication-popular science-that can inform and influence policy agendas and diplomatic proceedings, as well as popular movements. Popular science has long been particularly influential in the realm of environmental politics, which from at least the early 1960s has been conditioned by polemics like Rachel Carson's Silent Spring (Carson, 1962), Paul Ehrlich's The Population Bomb (Ehrlich, 1968), or Palmstierna's Plunder in Sweden. Grounded in scientific knowledge yet presented in accessible and emotive language for the purpose of convincing a potentially indifferent or skeptical lay audience of the rising importance and urgency of environmental problems, the popularized science co-produced and employed by Swedish scientists and diplomats over the course of Sweden's 1968 intervention at the United Nations played an indispensable role in the seminal moment of multilateral environmental diplomacy and global environmental governance.

\section{Data availability}

The datasets generated during and/or analyzed during the current study are available from the corresponding author on reasonable request.

Received: 10 July 2020; Accepted: 23 November 2020; Published online: 05 January 2021

\section{Notes}

1 Engfeldt L-G, personal communication.

2 Engfeldt L-G, personal communication.

3 Åström S, Sveriges ständiga representation vid förenta nationerna, memorandum to Swedish Foreign Ministry, March 13, 1968.

4 Bäckstrand G, personal communication.

5 "Statement by Mr. Börje Billner before the General Assembly on December 13, 1967, on agenda item 27, Question of holding further conferences on the peaceful sues of atomic energy".

6 Bäckstrand, Swedish Foreign Ministry, Promemoria April 11, 1968, "FN-konferens för miljövård".

7 Bäckstrand, Swedish Foreign Ministry, Promemoria April 25, 1968, "Kort resumé av diskussioner och beslut vid sammanträde med den förberedande arbetsgruppen för eventuell FN-konferens kring miljövårdsproblem”.

8 Palmstierna's text forwarded by Göran Bäckstrand from Swedish Foreign Ministry to Sweden's UN mission via telegram on May 10, 1968. "Question of convening a UN conference on the problems of human environment to be put on the agenda of ECOSOC:s 45th Session".

9 In letter sent by Lennart Eckerberg at the Swedish Foreign Ministry to Sverker Åström on July 5, 1968, "Översättning av svensk miljövårdsdokument till ECOSOC/ Anförande i FN:s Ekonomiska och sociala råd (ECOSOC)”.

10 "Statement by the Representative of Sweden, Ambassador Sverker Åström, on agenda items 5 (c) and (d) in the Economic Committee of the Economic and Social Council, May 24, 1968"; and, "Statement by Ambassador Sverker Åström, on agenda item 12 the question of convening an international Conference on the problems of human environment, in the ECOSOC meeting in Geneva, on July 19, 1968." Swedish Ministry for Foreign Affairs. 
11 The Explanatory Memorandum included a cover letter dated May 20, 1968 written by Sverker Åström and addressed to U.N. Secretary-General U Thant requesting that an item entitled "The question of convening an international conference on the problems of human environment" be inscribed on the agenda of the 45th Session of the Economic and Social Council.

12 Engfeldt L-G, personal communication.

13 According to Engfeldt (2009), the July 1968 ECOSOC was the first mention of climate change in a main U.N. organ.

14 Engfeldt L-G, personal communication.

15 "Statement by the Swedish Representative, Ambassador Sverker Åström, in the General Assembly on Tuesday, 3 December, 1968."

16 Palmstierna traced the actual problem of acid precipitation to approximately 1955 and the conversion to oil for heating and electricity generation in much of Europe.

17 Also Engfeldt L-G, personal communication. Based on his review of Foreign Ministry documents, Engfeldt disputes McCormick's (1989) claim that the Swedish initiative was motivated by parochial concerns over acid rain.

18 Engfeldt L-G, personal communication.

19 Engfeldt L-G, personal communication.

20 Engfeldt L-G, personal communication.

21 Arguably one of the most prominent scientist-diplomats of the twentieth century's second half, Bolin would later become, in 1988, founding chairman of the Intergovernmental Panel on Climate Change (Paglia and Parker, 2021).

22 Bäckstrand $\mathrm{G}$, personal communication.

23 The English version of Sweden's national report also included explanations in Arabic, Chinese, French, Russian and Spanish, demonstrating the complementary pedagogical purpose of the report.

24 The other thematic reports were on work environments (Royal Ministry of Foreign Affairs/Royal Ministry of Agriculture 1971a, 1971b) and the connection between urbanization and stress (Carlestam and Levi, 1971).

25 Engfeldt L-G, personal communication; Bäckstrand G, personal communication.

26 Bäckstrand G, Ingelstam L, Engfeldt L-G, personal communications.

27 Ingelstam $\mathrm{L}$, personal communication.

\section{References}

Antrim L (1994) Dynamics of leadership in UNCED. In: Spector B, Sjöstedt G, Zartman IW (eds) Negotiating international regimes: lessons learned from the united nations conference on environment and development (UNCED). Graham \& Trotman, London, pp. 149-164

Åström S (1992) Ögonblick: från ett halvsekel i UD-tjänst. Bonnier Alba, Stockholm

Fichtelius K-E (ed) (1967) Människans villkor: En bok av vetenskapsmän för politiker. Wahlström \& Widstrand, Stockholm

Bäckstrand G (1971) Internationell miljövård på väg? Utrikespolitiska institutet, Stockholm

Bäckstrand G (1972) Utveckling och miljö i u-länderna. Prisma, Stockholm

Bolin B, Granat L, Ingelstam L, Johannesson M, Mattsson E, Oden S, Rodhe H, Tamm CO (1971) Air pollution across national boundaries: the impact on the environment of sulfur in air and precipitation. Sweden's case study for the United Nations Conference on the Human Environment. Royal Ministry for Foreign Affairs and Royal Ministry of Agriculture, Stockholm

Caldwell LK (1990) International environmental policy: emergence and dimensions. Duke University Press, Durham and London

Carlestam G, Levi L (1971) Urban conglomerates as psycho-social human stressors: general aspects, Swedish trends, and psychological and medical implications: a contribution to the United Nations Conference on the Human Environment. Royal Ministry for Foreign Affairs/Royal Ministry of Agriculture, Stockholm

Carson R (1962) Silent spring. Houghton Mifflin, Boston

Royal Society (2010) New frontiers in science diplomacy: navigating the changing balance of power. The Royal Society, London

Collins H (2004) Interactional expertise as a third kind of knowledge. Phenomenol Cogn Sci 3:125-143

Carroll JE (ed) (1988) International environmental diplomacy. Cambridge University Press, Cambridge

Ehrlich P (1968) The population bomb. Sierra Club/Ballantine Books, New York, NY

Engfeldt L-G (1973) The united nations and the human environment-some experiences. Int Organ 27(3):393-412. https://doi.org/10.1017/ S002081830000357X

Engfeldt L-G (2009) From Stockholm to Johannesburg and beyond: the evolution of the international system for sustainable development governance and its implications. Government Offices of Sweden, Stockholm

Engfeldt L-G (2019) Diplomati i förändring: I UD:s tjänst 1965-2009. Ekerlids Förlag, Stockholm

Flink T, Rüffin N (2019) The current state of the art of science diplomacy. In: Simon D, Kuhlmann S, Canzler W, Stamm J (eds) Handbook on science and public policy. Edward Elgar, Cheltenham, pp. 104-121
Gluckman PD, Turekian VC, Grimes RW, Kishi T (2017) Science diplomacy: a pragmatic perspective from the inside. Sci Diplom 6(4). http://www. sciencediplomacy.org/article/2018/pragmatic-perspective

Grieger A (2012) Only one earth: Stockholm and the beginning of modern environmental diplomacy. Arcadia 10. Environment and Society Portal, Rachel Carson Center for Environment and Society. https://doi.org/10.5282/ $\mathrm{rcc} / 3867$

Heidenblad DL (2018) Mapping a new history of the ecological turn: the circulation of environmental knowledge in Sweden 1967. Environment and History 24(2):265-284

Heidenblad DL (2019) Överlevnadsdebattörerna: Hans Palmstierna, Karl-Erik Fichtelius och miljöfrågornas genombrott i 1960-talets Sverige. In: Norén F, Stjernholm E (eds) Efterkrigstidens samhällskontakter, Mediehistoriskt arkiv 43. Lund University, Lund, pp 157-184

Ingelstam L (2012) System: att tänka över samhälle och teknik. Statens energimyndighet, Eskilstuna

Ivanova M (2010) Moving forward by looking back: Learning from UNEP's history. In: Conca K, Dabelko G (eds) Green planet blues. Four Decades of Global Environmental Politics Westview Press, Boulder, pp. 143-160

Jamison A, Eyerman R, Cramer J, Læssøe J (1990) The making of the new environmental consciousness: a comparative study of the environmental movements in Sweden, Denmark and the Netherlands. Edinburgh University Press, Edinburgh

Javaudin E (2017) Environmental problem solvers? Scientists and the Stockholm Conference. In: Kaiser W, Meyer J-H (eds) International organizations \& environmental protection: conservation and globalization in the twentieth century. Berghahn, New York, NY

Kaltofen C, Acuto M (2018) Science Diplomacy: introduction to a Boundary Problem. Glob Policy 9(S3):8-14

Kennet W (1972) The stockholm conference on the human environment. Int Affairs 48(1):33-45

Kjellén BO (2007) A new diplomacy for sustainable development: the challenge of global change. Routledge, New York, NY

Linnér B-O, Selin H (2018) 50 years of global climate change debate: what's next? Mistra Geopolitics, available at: https://www.mistra-geopolitics.se/news/ what-happened-3-december-1968/. (accessed 5 Jun 2020)

Lundgren L (2005) Konflikter, samarbete, resultat: Perspektiv på svensk miljöpolitik: Festskrift till Valfrid Paulsson. Kassandra, Brottby

Macekura S (2015) Of limits and growth: the rise of global sustainable development in the twentieth century. Cambridge University Press, Cambridge UK

Marklund C (2019) Double loyalties? Small-state solidarity and the debates on new international economic order in sweden during the long 1970s. Scand J Hist https://doi.org/10.1080/03468755.2019.1624606

Mårtenson J (2000) Att kyssa ett träd: memoarer. Wahlström \& Widstrand Stockholm

McCormick J (1989) Reclaiming paradise: the global environmental movement. Indiana University Press, Bloomington and Indianapolis

McNeill J (2000) Something new under the sun: an environmental history of the twentieth century. W.W. Norton \& Company, New York, NY

Meadows D et al. (1972) The limits to growth; a report for the club of Rome's project on the predicament of mankind. Universe Books, New York, NY

Moomaw W (2018) Scientist diplomats or diplomat scientists: who makes science diplomacy effective? Glob Policy 9(S3):78-80

Najam A, Papa M, Taiyab N (2006) Global environmental governance: a reform agenda. International Institute for Sustainable Development, Winnipeg

Odén S (1967) Nederbördens försurning. Dagens Nyheter, 24 October

Paglia E (2015) Not a proper crisis. The anthropocene review 2(3):247-261

Paglia E (2016) The northward course of the anthropocene: transformation, temporality and telecoupling in a time of environmental crisis. KTH Royal Institute of Technology, Stockholm

Paglia E (2018) The socio-scientific construction of global climate crisis. Geopolitics 23(1):96-123

Paglia E, Parker C (2021) The intergovernmental panel on climate change: guardian of climate science. In: Boin A, Fahy L, 't Hart P (eds) Guardians of public value: how public organisations become and remain institutions. Palgrave Macmillan, London

Paglia E, Isberg E (2021) (forthcoming) On record: Political temperature and the temporalities of climate change. In Ekström A, Bergwik S (eds) Times of History, Times of Nature: Temporalization and the Limits of Modern Knowledge. Berghahn Books, New York

Paglia E, Sörlin S (2021) (forthcoming) Greening ourcommon fate: Stockholm as a node of global environmental memory. In: Sluga G, Darian-Smith K, Herren $M$ (eds) Sites of international memory: a century of commemoration and internationalization. University of Pennsylvania Press, Philadelphia

Palmstierna H (1967) Plundring, svält, förgiftning. Rabén \& Sjögren, Stockholm

Rowland W (1973) The plot to save the world: the Stockholm conference on the human environment with an introduction by maurice strong. Clarke, Irwin \& Company, Toronto 
Royal Ministry for Foreign Affairs and Royal Ministry of Agriculture (1971a) Sweden's national report to the United Nations on the Human Environment. Royal Ministry for Foreign Affairs and Royal Ministry of Agriculture, Stockholm

Royal Ministry for Foreign Affairs and Royal Ministry of Agriculture (1971b) The human work environment: Swedish experiences, trends, and future problems: a contribution to the United Nations Conference on the Human Environment. Royal Ministry for Foreign Affairs and Royal Ministry of Agriculture, Stockholm

Rungius C, Flink T (2020) Romancing science for global solutions: on narratives and interpretative schemas of science diplomacy. Humanit Soc Sci Commun 7:102

Schleper S (2019) Planning for the planet: environmental expertise and the international union for conservation of nature and natural resources, 1960-1980. Berghahn Books, New York, NY

Selcer P (2018) The postwar origins of the global environment: how the united nations built spaceship earth. Colombia University Press, New York, NY

Sörlin S (2011) The contemporaneity of environmental history: negotiating scholarship, useful history, and the new human condition. J Contem Hist 46 (3):610-630

Speth JG, Haas P (2006) Global environmental governance. Island Press, Washington, DC

Stone P (1973) Did we save the Earth at Stockholm? The people and politics in the Conference on the Human Environment. Earth Island, London

Strong M (1972) The Stockholm conference: where science and politics meet. Ambio 1(3):73-78

Strong M (2000) Where on earth are we going? Texere, New York, NY

Tolba M (1998) Global environmental diplomacy: negotiating environmental agreements for the world, 1973-1992. The MIT Press, Cambridge

United Nations General Assembly (UNGA) (1968) Resolution 2398 (XXIII) The problems of the human environment. United Nations, New York, NY

Ward B, Dubos R (1972) Only One Earth: the care and maintenance of a small planet. W.W. Norton \& Company, New York, NY

Warde P, Robin L, Sörlin S (2018) The environment: a history of the idea. Johns Hopkins University Press, Baltimore

\section{Acknowledgements}

The author would like to thank Ambassador Lars-Göran Engfeldt, Göran Bäckstrand and Professor Lars Ingelstam for the invaluable oral histories they contributed to the research this article is based upon, and Professor Sverker Sörlin for the comments he provided during the writing of the article. This work was supported by the European Research Council (ERC) under the European Union's Horizon 2020 research and innovation program, grant agreement No 787516: "The Rise of Global Environmental Governance: A History of the Contemporary Human-Earth Relationship-GLOBEGOV" (it reflects only the author's views and the ERC is not responsible for any use that may be made of the information it contains)". The project is also known as SPHERE-Study of the Planetary Human-Environment Relationship.

\section{Funding}

Open Access funding provided by Kungliga Tekniska Hogskolan.

\section{Competing interests}

The author declares no competing interests.

\section{Additional information}

Correspondence and requests for materials should be addressed to E.P.

Reprints and permission information is available at http://www.nature.com/reprints

Publisher's note Springer Nature remains neutral with regard to jurisdictional claims in published maps and institutional affiliations.

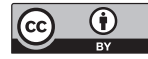

Open Access This article is licensed under a Creative Commons Attribution 4.0 International License, which permits use, sharing, adaptation, distribution and reproduction in any medium or format, as long as you give appropriate credit to the original author(s) and the source, provide a link to the Creative Commons license, and indicate if changes were made. The images or other third party material in this article are included in the article's Creative Commons license, unless indicated otherwise in a credit line to the material. If material is not included in the article's Creative Commons license and your intended use is not permitted by statutory regulation or exceeds the permitted use, you will need to obtain permission directly from the copyright holder. To view a copy of this license, visit http://creativecommons.org/ licenses/by/4.0/.

(C) The Author(s) 2021 